\title{
EFFECT OF SUPERABSORBENT POLYMER ON SALT AND DROUGHT RESISTANCE OF EUCALYPTUS GLOBULUS
}

\author{
KHODADADI DEHKORDI, D. \\ Department of Water Engineering and Sciences, Ahvaz Branch, Islamic Azad University, \\ Ahvaz, Iran \\ e-mail:davood_kh70@yahoo.com,dkhodadadi@iauahvaz.ac.ir; tel: +989163033474 \\ (Received $13^{\text {th }}$ Jun 2017; accepted $5^{\text {th }}$ Oct 2017)
}

\begin{abstract}
In this study, the effect of Super-AB-A-200 polymer on salt and drought resistance of Eucalyptus globulus Labill. was evaluated. The treatments were: (1) Control, Control + polymer; (2) $\mathrm{NaCl}, \mathrm{NaCl}+$ polymer; (3) Drought, Drought + polymer; (4) Drought $+\mathrm{NaCl}$, Drought $+\mathrm{NaCl}+$ polymer. The results showed that Super-AB-A-200 in root medium helped E. globulus cuttings to resist the salinity and drought stresses, because of the following reasons: (1) E. globulus roots absorbed the held water from Super-AB-A-200 polymer in soil water-deficit conditions; (2) in saline conditions, Super-AB-A-200 retained $\mathrm{Cl}^{-}$and $\mathrm{Na}^{+}$in the soil solution because of their high water-holding capability, moreover, the exchangeable $\mathrm{K}^{+}$included in Super-AB-A-200 resulted in an amended $\mathrm{K}^{+} / \mathrm{Na}^{+}$balance in salinized plants; (3) Super-AB-A-200 helped E. globulus cuttings to resist interactive effects of salinity and drought stresses, which was essentially justified by their salt- and water-holding capabilities.
\end{abstract}

Keywords: acrylate polymers, gas-exchange, salinity stress, water-saving agriculture, water use efficiency

\section{Introduction}

A lot of countries have not sufficient water resources to confront their actual environmental, urban and agricultural requirements. With increasing water deficiency, population and water claims are increasing simultaneously (Bouwer, 2002). Superabsorbent polymer (SAP) perform as a soil reformer to decrease soil water loss and increase crop yield. SAP is a hydrophilic polymer that can store and take up 1000 times more water or aquatic solutions than its first weight and size (Sojka and Entry, 2000). Therefore, SAP can increase soil water-holding capacity and nutrient use efficiency (Lentz et al., 1998) and decrease water loss (Al-Omran and Al-Harbi, 1997). SAP is applied in the soil to make a water supply, near the rhizosphere zone and advantage agriculture (Han et al., 2010). Because of the water resource crisis, watersaving agriculture is necessary for the sustainable development. Moreover, droughts are anticipated to be increasingly crucial because of climate change (Gornall et al., 2010). Hydrophilic polymers are usually cross-linked 3-D hydrophilic nets that are able to take up and keep noteworthy values of aquatic liquids even in certain pressure or temperature. SAPs are able to perform in several fields like agriculture (Puoci et al., 2008), sanitary productions (Kosemund et al., 2009), waste water refining (Kasgoz and Durmus, 2008; Kasgoz et al., 2008; Wang et al., 2008a). SAPs are in three types containing natural, semi-artificial and artificial (Mikkelsen, 1999). Unnatural polymers applied more than natural ones because they have more endurance against environmental collapse (Peterson, 2002). Superabsorbent minimizes micronutrients from washing out to the water table and causes more water use efficiency, a decline in costs of irrigation and intervals by 50 percent water stress and damages to transplant during transferring (Abedi Koupai and Mesforoush, 2009). Teimouri and Sharifan (2013) assessed the effect of $\mathrm{KCl}$ and $\mathrm{NaCl}$ in varied concentrations on dehydration and hydration of some SAPs. According to the results, Super-AB-A-200 and Colophony had 
the most hydration and dehydration respectively. Fazeli-Rostampoor et al. (2011) showed that drought stress and applying Super-AB-A-200 had a significant effect on increasing corn grain yield and water use efficiency. Li et al. (2014) reported that the addition of SAPs significantly increased the soil water content and soil maximum hygroscopic moisture in the booting and filling stages but had no effects on the soil available water-holding capacity compared with the control in the filling stage. Yadollahi et al. (2012) assessed the impact of Super-AB-A-200 and organic matters in soil water retention and construction of almond orchards in rainfed conditions. The results showed that Super-AB-A-200 and organic matters could increase soil water retention significantly. Besides, this conditions could increase growth indices of almond seedlings. Eucalyptus globulus is a woodland tree and native to Australia, however, it has been planted in Iran and is under evaluation. In spite of ecological importance, Eucalyptus has important medicinal and horticultural worth and several species are applied for forest landscape and street planting. The E. globulus trees are used in the south of Iran as park landscape and street planting. Besides, salinity and drought stresses are essential restrictions for their survival. SAPs may help them to tolerate these harmful stresses. The aim of this study was to evaluate the effects of Super-AB-A-200 polymer on salt and drought resistance in Eucalyptus globulus Labill.

\section{Materials and Methods}

\section{Hydrophilic polymer}

The hydrophilic polymer Super-AB-A-200, produced by Rahab Resin Co. with product license holding of Iran Polymer and Petrochemical Institute (Rahab Resin Co, 2016), was used in this study (Table 1). This hydrophilic polymer is a granular-type tripolymer of acrylamide, acrylic acid, and acrylate potassium.

Table 1. The characteristics of Super-AB-A-200 polymer

\begin{tabular}{cc}
\hline Characteristics & Super-AB-A-200 polymer \\
\hline Shape & Granular \\
Density & $1.4-1.5\left(\mathrm{gr}_{\mathrm{cm}} \mathrm{cm}^{-3}\right)$ \\
Size of particles & $50-150(\mu \mathrm{m})$ \\
Maximum stability in soil & $7(\mathrm{year})$ \\
Practical capacity of water uptake & $220\left(\mathrm{~g} . \mathrm{g}^{-1}\right)$ \\
\hline
\end{tabular}

\section{Experimental treatments}

One-year-old cuttings of Eucalyptus globulus (48 plants) were obtained from a nursery under natural conditions near Shush, Iran. The cuttings were planted separately in 6-L pots filled with sandy soil. Prior to treatment, the plants were grown in a greenhouse and well-irrigated with $1000 \mathrm{~mL}$ of Hoagland's nutrient solution every 15 days. Uniform plants with a height of about $90 \mathrm{~cm}$ were collected for this study. The plants were transferred to $15-\mathrm{L}$ pots randomly filled with either saline soil (sandy soil pretreated with $2000 \mathrm{~mL}$ of $300 \mathrm{mM} \mathrm{NaCl}$ ) or a control soil without the $\mathrm{NaCl}$ with the polymer or without it ( $0.5 \%$ of dry weight). The four treatment groups were classified as follows: (1) Control + Super-AB-A-200, Control; (2) NaCl + Super-AB-A-200, NaCl; 
(3) Drought + Super-AB-A-200, Drought; (4) $\mathrm{NaCl}+$ Drought + Super-AB-A-200, $\mathrm{NaCl}+$ Drought. The drought treatment was applied after the start of water-deficit stress by withholding irrigation, but the control plants were well-irrigated.

\section{Plant harvesting}

The experimental plants were harvested (three replicate plants for each treatment) after 40 days of exposure to drought and salinity treatments. Plant roots were thoroughly washed with deionized water to remove soil. The fresh weights of the leaves, roots, and stems were assessed and the tissues were dried in an oven at $65^{\circ} \mathrm{C}$ for $5-7$ days to determine the dry weight. Dried samples were ground into powder and stored for analysis.

\section{Plant water usage capacity}

Each pot containing one plant was covered by a plastic case and protected at the stem base to stop rainfall and soil evaporation. The water usage was measured as the daily weight loss of the pot and the plant together over a 12-h period (08:00-20:00) on days $4,8,12,16$, and 20 and the mean value of each plant was recorded. Three individual replicates were examined for each treatment.

\section{Gas-exchange of leaves}

The gas-exchange of the 5th through 7 th leaves of the E. globulus shoots was determined on days 17, 28, 34, 36, and 38 and the mean value of each plant was recorded (the radiation of natural light was greater than $600 \mu \mathrm{mol} \mathrm{m} \mathrm{m}^{-2} \mathrm{~s}^{-1}$ ). Stomatal conductivity (Gs), net photosynthetic rates (Pn), and leaf transpiration rates (TRN) were recorded between 9:00-10:30 a.m. with a CIRAS-3 Portable Photosynthesis System (PP Systems, Amesbury, MA, USA) where the photosynthetically active radiation (PAR) was approximately $1300 \mu \mathrm{mol} \mathrm{m} \mathrm{m}^{-2} \mathrm{~s}^{-1}$. If the PAR was very low, the light was supplemented by halogen lamps (Shi et al., 2010). Leaf temperatures were 30 to $35^{\circ} \mathrm{C}$ during the measurements.

\section{Ion analysis of roots and leaves}

Ion analysis was conducted according to Storey (1995). Dried samples (1 g) of roots and leaves were extracted with $2 \mathrm{NHNO}_{3} . \mathrm{K}^{+}$and $\mathrm{Na}^{+}$were measured by an atomic absorption spectrometer (AAS) (PerkinElmer 2380). PerkinElmer 2380 is a doublebeam, optical system and high-dispersion monochromator with a wavelength range of 190 to $870 \mathrm{~nm}$. $\mathrm{Cl}^{-}$was measured by an adjusted method of silver titration. A solution of $\mathrm{AgNO}_{3}(0.027 \mathrm{~N})$ was applied to the sediment the $\mathrm{Cl}^{-}$of aquatic extracts and surplus, $\mathrm{Ag}^{+}$was evaluated by $\mathrm{NH}_{4} \mathrm{SCN}(0.01 \mathrm{~N})$ titration. $\mathrm{NH}_{4} \mathrm{Fe}\left(\mathrm{SO}_{4}\right)_{2}$ was applied as a color indicator for ionic spot assignment. Concentrations of $\mathrm{Cl}^{-}$were determined by the equation (1) as follows (Shi et al., 2010):

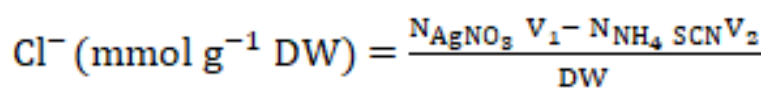

where

DW: dry weight $(\mathrm{g})$

$\mathrm{V}_{1}$ : total volume of the $\mathrm{AgNO}_{3}$ solution in chloride extracts $(\mathrm{mL})$,

$\mathrm{V}_{2}$ : volume of the $\mathrm{NH}_{4} \mathrm{SCN}$ solution, applied for surplus $\mathrm{Ag}^{+}$sediment $(\mathrm{mL})$. 


\section{Soil ion analysis}

The soil was sampled at harvest and the soil water content was tested. The soil sample extracts (dried soil:deionized water $=1: 5, \mathrm{w} / \mathrm{v}$ ) were used to measure $\mathrm{Cl}^{-}, \mathrm{K}^{+}$, and $\mathrm{Na}^{+}$contents. $\mathrm{K}^{+}$and $\mathrm{Na}^{+}$were measured by AAS (PerkinElmer 2380) at 771 and $594 \mathrm{~nm}$, respectively; and $\mathrm{Cl}^{-}$was measured by silver titration.

\section{The analysis of data}

ANOVA was used to compare the data and significant differences between mean values were measured by Duncan's multiple range test. Differences between means were designated as statistically significant when $p<0.05$.

\section{Results}

\section{Salinity and drought stress-induced leaf damages}

Leaf damage gradually increased as the soil water deficit increased and about $40 \%$ of E. globulus leaves were withered after 40 days of drought treatment (Figure 1).

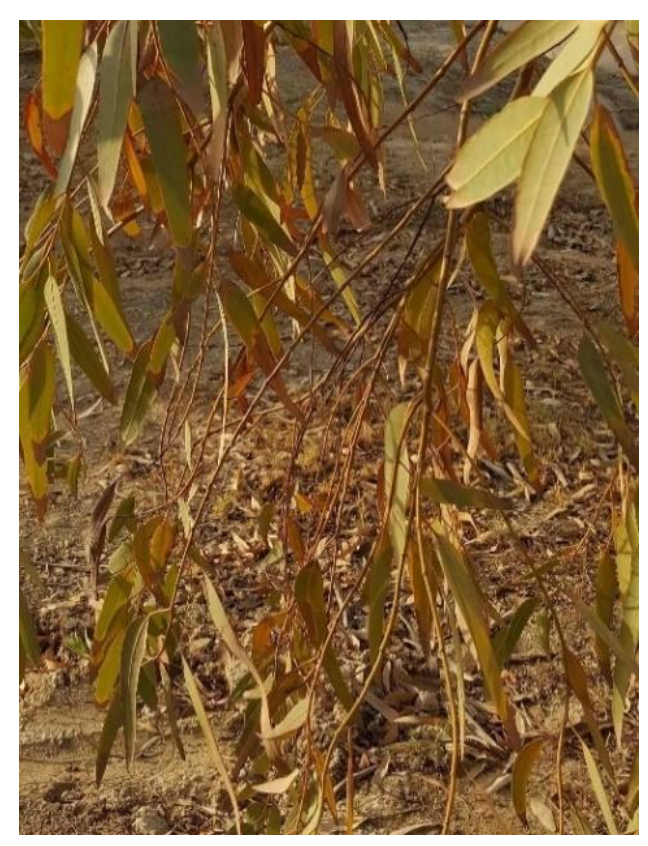

Figure 1. The withered leaves of E. globulus

\section{Dry weight of plant}

The dry weights of the E. globulus stems, roots, leaves, and whole plants were significantly reduced under salinity and/or drought stresses compared to the control. However, the $\mathrm{NaCl}+$ Drought treatment did not decrease dry weight more than the salt and drought stresses alone (Table 2). The plants treated with the Super-AB-A-200 polymer had higher dry weights compared to the plants without the polymer in all treatments (Table 2). The stem, leaf, and whole plant dry weights in the $\mathrm{NaCl}+$ Drought + polymer treatment were not significantly different from the control. This indicated that the Super-AB-A-200 polymer improved growth under salinity stress, especially in 
drought conditions. In addition, the Super-AB-A-200 polymer significantly improved the dry weights of the E. globulus stems, roots, leaves, and whole plants in the $\mathrm{NaCl}$, drought, and $\mathrm{NaCl}+$ Drought treatments (Table 2).

Table 2. The effect of Super-AB-A-200 polymer on dry weight of stems, roots, leaves and whole plants of Eucalyptus globulus under $\mathrm{NaCl}$ and/or drought stresses

\begin{tabular}{|c|c|c|c|}
\hline Dry weight (g) & Treatment & - Polymer & + Super-AB-A-200 \\
\hline \multirow{4}{*}{ Root } & Control & $15.23 \mathrm{a}^{\mathrm{A}}$ & $15.78 \mathrm{a}^{\mathrm{A}}$ \\
\hline & $\mathrm{NaCl}$ & $10.42 b^{B}$ & $12.71 \mathrm{a}^{\mathrm{B}}$ \\
\hline & Drought & $10.63 b^{B}$ & $12.48 \mathrm{a}^{\mathrm{B}}$ \\
\hline & $\mathrm{NaCl}+$ Drought & $10.21 b^{B}$ & $12.41 \mathrm{a}^{\mathrm{B}}$ \\
\hline \multirow{4}{*}{ Leaf } & Control & $16.25 \mathrm{a}^{\mathrm{A}}$ & $16.51 \mathrm{a}^{\mathrm{A}}$ \\
\hline & $\mathrm{NaCl}$ & $11.48 b^{\mathrm{B}}$ & $13.69 \mathrm{a}^{\mathrm{B}}$ \\
\hline & Drought & $11.68 b^{B}$ & $12.67 \mathrm{a}^{\mathrm{B}}$ \\
\hline & $\mathrm{NaCl}+$ Drought & $11.31 b^{\mathrm{B}}$ & $14.98 \mathrm{a}^{\mathrm{B}}$ \\
\hline \multirow{4}{*}{ Stem } & Control & $16.49 \mathrm{a}^{\mathrm{A}}$ & $16.41 \mathrm{a}^{\mathrm{A}}$ \\
\hline & $\mathrm{NaCl}$ & $11.45 b^{\mathrm{B}}$ & $13.21 \mathrm{a}^{\mathrm{B}}$ \\
\hline & Drought & $11.74 b^{B}$ & $12.88 \mathrm{a}^{\mathrm{B}}$ \\
\hline & $\mathrm{NaCl}+$ Drought & $11.39 b^{\mathrm{B}}$ & $14.17 \mathrm{a}^{\mathrm{B}}$ \\
\hline \multirow{4}{*}{ Plant } & Control & $52.56 \mathrm{a}^{\mathrm{A}}$ & $53.88 \mathrm{a}^{\mathrm{A}}$ \\
\hline & $\mathrm{NaCl}$ & $39.61 b^{\mathrm{B}}$ & $45.56 \mathrm{a}^{\mathrm{B}}$ \\
\hline & Drought & $40.43 b^{\mathrm{B}}$ & $44.14 \mathrm{a}^{\mathrm{B}}$ \\
\hline & $\mathrm{NaCl}+$ Drought & $39.12 b^{\text {B }}$ & $47.68 \mathrm{a}^{\mathrm{B}}$ \\
\hline
\end{tabular}

Every value is the average of three separate plants. Values pursued by varied letters in the similar column (A, B) or the similar row (a, b) are significantly varied at $\mathrm{p}<0.05$.

\section{Plant water use efficiency}

The daily water use of the E. globulus cuttings was reduced under salinity or drought stress in the presence of the polymer, and this decline was further evident in the $\mathrm{NaCl}+$ Drought treatment (Table 3).

Table 3. The effect of Super-AB-A-200 polymer on plant water use $\left(\mathrm{gH}_{2} \mathrm{Oday}^{-1}\right)$ in Eucalyptus globulus plants under $\mathrm{NaCl}$ and/or drought stresses

\begin{tabular}{ccc}
\hline Treatment & - Polymer & + Super-AB-A-200 \\
\hline Control & $164.5 \mathrm{a}^{\mathrm{A}}$ & $168.6 \mathrm{a}^{\mathrm{AB}}$ \\
$\mathrm{NaCl}$ & $141.8 \mathrm{~b}^{\mathrm{B}}$ & $165.9 \mathrm{a}^{\mathrm{AB}}$ \\
Drought & $129.4 \mathrm{~b}^{\mathrm{B}}$ & $153.1 \mathrm{a}^{\mathrm{B}}$ \\
$\mathrm{NaCl}+$ Drought & $95.7 \mathrm{~b}^{\mathrm{C}}$ & $177.6 \mathrm{a}^{\mathrm{A}}$ \\
\hline
\end{tabular}

Every value is the average of three separate plants. Values pursued by varied letters in the similar column $(\mathrm{A}, \mathrm{B}, \mathrm{C})$ or the similar row $(\mathrm{a}, \mathrm{b})$ are significantly varied at $\mathrm{p}<0.05$. 


\section{Gas-exchange of leaves}

The transpiration rates (TRN), net photosynthetic rates $(\mathrm{Pn})$, and leaf stomatal conductivity (Gs) of the E. globulus cuttings was reduced over time in the salinity or drought stress treatments (Table 4). In the $\mathrm{NaCl}+$ Drought treatment the TRN, Pn, and Gs was reduced by 30\%, 48\%, and 55\%, respectively (Table 4). The addition of SuperAB-A-200 increased the gas-exchange in the NaCl-, Drought-, and $\mathrm{NaCl}+$ Droughttreated plants (Table 4). The effect of the Super-AB-A-200 on the gas-exchange in the drought-stressed plants was significantly higher than the NaCl-treated plants (Table 4).

Table 4. The effect of Super-AB-A-200 polymer on transpiration rates (TRN), net photosynthetic rates (Pn) and leaf stomatal conductivity (Gs) in Eucalyptus globulus plants under $\mathrm{NaCl}$ and/or drought stresses

\begin{tabular}{|c|c|c|c|}
\hline Gas-exchange & Treatment & - Polymer & + Super-AB-A-200 \\
\hline \multirow{4}{*}{ Gs $\left(\mathrm{mmol} \mathrm{m} \mathrm{m}^{-2} \mathrm{~s}^{-1}\right)$} & Control & $138.56 \mathrm{a}^{\mathrm{A}}$ & $144.32 \mathrm{a}^{\mathrm{A}}$ \\
\hline & $\mathrm{NaCl}$ & $95.22 b^{B}$ & $113.76 \mathrm{a}^{\mathrm{B}}$ \\
\hline & Drought & $96.51 b^{B}$ & $168.58 \mathrm{a}^{\mathrm{A}}$ \\
\hline & $\mathrm{NaCl}+$ Drought & $62.49 b^{C}$ & $130.28 \mathrm{a}^{\mathrm{AB}}$ \\
\hline \multirow{4}{*}{ TRN $\left(\mathrm{mmol} \mathrm{m}^{-2} \mathrm{~s}^{-1}\right)$} & Control & $4.21 \mathrm{a}^{\mathrm{A}}$ & $4.45 \mathrm{a}^{\mathrm{AB}}$ \\
\hline & $\mathrm{NaCl}$ & $3.51 b^{B}$ & $4.18 \mathrm{a}^{\mathrm{B}}$ \\
\hline & Drought & $3.97 b^{\mathrm{AB}}$ & $5.15 \mathrm{a}^{\mathrm{A}}$ \\
\hline & $\mathrm{NaCl}+$ Drought & $2.96 b^{C}$ & $4.49 \mathrm{a}^{\mathrm{AB}}$ \\
\hline \multirow{4}{*}{$\operatorname{Pn}\left(\mu \mathrm{mol} \mathrm{m}{ }^{-2} \mathrm{~s}^{-1}\right)$} & Control & $14.12 \mathrm{a}^{\mathrm{A}}$ & $14.85 \mathrm{a}^{\mathrm{A}}$ \\
\hline & $\mathrm{NaCl}$ & $10.65 b^{B}$ & $12.35 \mathrm{a}^{\mathrm{B}}$ \\
\hline & Drought & $10.75 b^{B}$ & $14.30 \mathrm{a}^{\mathrm{A}}$ \\
\hline & $\mathrm{NaCl}+$ Drought & $7.35 b^{C}$ & $11.91 \mathrm{a}^{\mathrm{B}}$ \\
\hline
\end{tabular}

Every value is the average of three separate plants. Values pursued by varied letters in the similar column (A, B, C) or the similar row $(\mathrm{a}, \mathrm{b})$ are significantly varied at $\mathrm{p}<0.05$.

\section{Ion concentrations in roots and leaves}

The concentrations of $\mathrm{Cl}^{-}$and $\mathrm{Na}^{+}$in the leaves and roots of E. globulus significantly increased after 40 days of $\mathrm{NaCl}$ treatment compared to the control and the drought stress aggravated the increased ion concentrations in salinized plants, particularly $\mathrm{Cl}^{-}$(Table 5). Application of Super-AB-A-200 polymer decreased the accumulation of $\mathrm{Cl}^{-}$and $\mathrm{Na}^{+}$ in leaves and roots in the presence or absence of drought stress and could confine $\mathrm{Cl}^{-}$ and $\mathrm{Na}^{+}$in $\mathrm{NaCl}+$ Drought-treated plant organs (Table 5). The Super-AB-A-200 polymer did not significantly affect the concentrations of $\mathrm{Cl}^{-}$and $\mathrm{Na}^{+}$in the leaves and roots under drought stress conditions, with some exceptions (Table 5). The $\mathrm{NaCl}$ treatment decreased the concentration of $\mathrm{K}^{+}$in the roots irrespective of drought treatment, but this did not occur in the leaves (Table 5). Moreover, the addition of Super-AB-A-200 altered $\mathrm{K}^{+}$in leaves and roots of drought-stressed plants (Table 5). 
Table 5. The effect of Super-AB-A-200 polymer on $\mathrm{K}^{+}, \mathrm{Cl}^{-}$and $\mathrm{Na}^{+}$concentrations in roots and leaves of Eucalyptus globulus plants under $\mathrm{NaCl}$ and/or drought stresses

\begin{tabular}{|c|c|c|c|}
\hline Ion concentration & Treatment & - Polymer & + Super-AB-A-200 \\
\hline \multicolumn{4}{|l|}{ Leaf } \\
\hline \multirow{4}{*}{$\mathrm{Na}^{+}(\mathrm{mM})$} & Control & $0.019 \mathrm{a}^{\mathrm{B}}$ & $0.019 \mathrm{a}^{\mathrm{B}}$ \\
\hline & $\mathrm{NaCl}$ & $0.074 \mathrm{a}^{\mathrm{A}}$ & $0.048 \mathrm{~b}^{\mathrm{A}}$ \\
\hline & Drought & $0.033 \mathrm{a}^{\mathrm{B}}$ & $0.043 \mathrm{a}^{\mathrm{A}}$ \\
\hline & $\mathrm{NaCl}+$ Drought & $0.078 \mathrm{a}^{\mathrm{A}}$ & $0.025 b^{\mathrm{B}}$ \\
\hline \multirow{4}{*}{$\mathrm{Cl}^{-}(\mathrm{mM})$} & Control & $0.105 \mathrm{a}^{\mathrm{C}}$ & $0.098 \mathrm{a}^{\mathrm{B}}$ \\
\hline & $\mathrm{NaCl}$ & $0.211 \mathrm{a}^{\mathrm{A}}$ & $0.145 b^{A}$ \\
\hline & Drought & $0.171 \mathrm{a}^{\mathrm{B}}$ & $0.178 \mathrm{a}^{\mathrm{A}}$ \\
\hline & $\mathrm{NaCl}+$ Drought & $0.235 \mathrm{a}^{\mathrm{A}}$ & $0.065 b^{\mathrm{B}}$ \\
\hline \multirow{4}{*}{$\mathrm{K}^{+}(\mathrm{mM})$} & Control & $0.022 b^{A}$ & $0.101 \mathrm{a}^{\mathrm{A}}$ \\
\hline & $\mathrm{NaCl}$ & $0.020 \mathrm{~b}^{\mathrm{A}}$ & $0.105 \mathrm{a}^{\mathrm{A}}$ \\
\hline & Drought & $0.024 b^{\mathrm{A}}$ & $0.127 \mathrm{a}^{\mathrm{A}}$ \\
\hline & $\mathrm{NaCl}+$ Drought & $0.026 b^{\mathrm{A}}$ & $0.113 \mathrm{a}^{\mathrm{A}}$ \\
\hline \multicolumn{4}{|l|}{ Root } \\
\hline \multirow{4}{*}{$\mathrm{Na}^{+}(\mathrm{mM})$} & Control & $0.058 \mathrm{a}^{\mathrm{B}}$ & $0.060 \mathrm{a}^{\mathrm{A}}$ \\
\hline & $\mathrm{NaCl}$ & $0.101 \mathrm{a}^{\mathrm{A}}$ & $0.076 b^{\mathrm{A}}$ \\
\hline & Drought & $0.061 \mathrm{a}^{\mathrm{B}}$ & $0.085 \mathrm{a}^{\mathrm{A}}$ \\
\hline & $\mathrm{NaCl}+$ Drought & $0.102 \mathrm{a}^{\mathrm{A}}$ & $0.063 \mathrm{~b}^{\mathrm{A}}$ \\
\hline \multirow{4}{*}{$\mathrm{Cl}^{-}(\mathrm{mM})$} & Control & $0.112 \mathrm{a}^{\mathrm{C}}$ & $0.108 \mathrm{a}^{\mathrm{A}}$ \\
\hline & $\mathrm{NaCl}$ & $0.215 \mathrm{a}^{\mathrm{B}}$ & $0.087 b^{A}$ \\
\hline & Drought & $0.181 \mathrm{a}^{\mathrm{B}}$ & $0.074 \mathrm{~b}^{\mathrm{A}}$ \\
\hline & $\mathrm{NaCl}+$ Drought & $0.356 \mathrm{a}^{\mathrm{A}}$ & $0.106 \mathrm{~b}^{\mathrm{A}}$ \\
\hline \multirow{4}{*}{$\mathrm{K}^{+}(\mathrm{mM})$} & Control & $0.415 b^{A}$ & $2.05 \mathrm{a}^{\mathrm{A}}$ \\
\hline & $\mathrm{NaCl}$ & $0.295 b^{B}$ & $2.66 \mathrm{a}^{\mathrm{A}}$ \\
\hline & Drought & $0.404 \mathrm{~b}^{\mathrm{A}}$ & $1.97 \mathrm{a}^{\mathrm{A}}$ \\
\hline & $\mathrm{NaCl}+$ Drought & $0.331 b^{B}$ & $2.51 \mathrm{a}^{\mathrm{A}}$ \\
\hline
\end{tabular}

Every value is the average of three separate plants. Values pursued by varied letters in the similar column (A, B, C) or the similar row (a, b) are significantly varied at $\mathrm{p}<0.05$.

\section{Ion concentrations in soils}

As expected, the concentrations of $\mathrm{Cl}^{-}$and $\mathrm{Na}^{+}$increased significantly in the $\mathrm{NaCl}$ treated soils compared to the control soils, and drought stress increased the soil salinity (Table 6). However, addition of the Super-AB-A-200 polymer reduced the $\mathrm{Cl}^{-}$and $\mathrm{Na}^{+}$ levels in the saline soil in both the $\mathrm{NaCl}$ and the $\mathrm{NaCl}+$ Drought treatments (Table 6). The Super-AB-A-200 treatments increased the $\mathrm{K}^{+}$concentration in the $\mathrm{NaCl}$-treated soil (Table 6). The $\mathrm{K}^{+}$concentration in the drought-treated soil was reduced by application of Super-AB-A-200; however, application of Super-AB-A-200 did not decrease the $\mathrm{K}^{+}$ level in $\mathrm{NaCl}+$ Drought-treated soil (Table 6). 
Table 6. The effect of Super-AB-A-200 polymer on $\mathrm{K}^{+}, \mathrm{Cl}^{-}$and $\mathrm{Na}^{+}$concentration in soil under salinity and/or drought treatments

\begin{tabular}{cccc}
\hline Ion concentration & Treatment & - Polymer & + Super-AB-A-200 \\
\hline \multirow{3}{*}{$\mathrm{Na}^{+}(\mathrm{mM})$} & Control & $8.32 \mathrm{a}^{\mathrm{C}}$ & $8.15 \mathrm{a}^{\mathrm{B}}$ \\
& $\mathrm{NaCl}$ & $64.35 \mathrm{a}^{\mathrm{B}}$ & $41.52 \mathrm{~b}^{\mathrm{A}}$ \\
& Drought & $19.26 \mathrm{a}^{\mathrm{C}}$ & $11.84 \mathrm{~b}^{\mathrm{B}}$ \\
& $\mathrm{NaCl}+$ Drought & $95.12 \mathrm{a}^{\mathrm{A}}$ & $21.46 \mathrm{~b}^{\mathrm{A}}$ \\
\hline & Control & $45.61 \mathrm{a}^{\mathrm{C}}$ & $47.55 \mathrm{a}^{\mathrm{B}}$ \\
& $\mathrm{NaCl}$ & $162.33 \mathrm{a}^{\mathrm{B}}$ & $104.66 \mathrm{~b}^{\mathrm{A}}$ \\
$\mathrm{Cl}^{-}(\mathrm{mM})$ & Drought & $180.22 \mathrm{a}^{\mathrm{B}}$ & $78.45 \mathrm{~b}^{\mathrm{A}}$ \\
& $\mathrm{NaCl}+$ Drought & $322.76 \mathrm{a}^{\mathrm{A}}$ & $59.64 \mathrm{~b}^{\mathrm{B}}$ \\
\hline & Control & $3.01 \mathrm{~b}^{\mathrm{B}}$ & $6.38 \mathrm{a}^{\mathrm{A}}$ \\
& NaCl & $3.05 \mathrm{~b}^{\mathrm{B}}$ & $10.66 \mathrm{a}^{\mathrm{A}}$ \\
& Drought & $7.53 \mathrm{a}^{\mathrm{A}}$ & $6.52 \mathrm{a}^{\mathrm{A}}$ \\
$\mathrm{K}^{+}(\mathrm{mM})$ & $\mathrm{NaCl}+$ Drought & $9.06 \mathrm{a}^{\mathrm{A}}$ & $8.47 \mathrm{a}^{\mathrm{A}}$ \\
& &
\end{tabular}

Every value is the average of three separate plants. Values pursued by varied letters in the similar column (A, B, C) or the similar row (a, b) are significantly varied at $\mathrm{p}<0.05$.

\section{Discussion}

\section{The effect of Super-AB-A-200 polymer on drought tolerance}

The Super-AB-A-200 polymer improved the growth in the E. globulus cuttings (Table 2) and reduced the occurrence of leaf damage caused by the drought treatments. These results are similar to other studies, in which the application of SAPs improved the growth of Citrus (Arbona et al., 2005), Eucalyptus (Viero and Little, 2006) and Populus popularis (Shi et al., 2010) in water-deficit conditions. Shi et al. (2010) reported that the application of SAPs improved the growth of $P$. popularis cuttings. The effects of SAPs result from the excess water retained by the SAP granules (Bouranis et al., 1995). Super-AB-A-200 polymer is a tripolymer of acrylamide, acrylic acid, and acrylate potassium. This hydrophilic polymer has tridimensional hydrophilic networks that can absorb and hold a large volume of water equal to hundreds of times its own weight (Abedi-Koupai and Asad-Kazemi, 2006; Marandi et al., 2009). Consequently, E. globulus roots absorb water held by the polymer. According to our results, E. globulus roots accumulated around the Super-AB-A-200 granules, rather than growing inside them. This result is consistent with the observation that drought-treated plants had fewer leaves, reduced gas-exchange and decreased plant water use without the polymer (Tables 4 and 3). Thus, the Super-AB-A-200 polymer lengthened the period of water supply for the plant.

\section{The effect of Super-AB-A-200 polymer on salt tolerance}

E. globulus is a semi-salt-tolerant species with a medium capacity for salt exclusion (Osareh and Shariat, 2009). Accumulation of salts in plant cells can cause toxicity and oxidative injury (Wang et al., 2007, 2008b). In this study, the increase of plant growth 
and leaf gas-exchange in the polymer-treated E. globulus plants is likely due to its increased capability for salt exclusion. When amended with the Super-AB-A-200 polymer, the $\mathrm{Cl}^{-}$and $\mathrm{Na}^{+}$concentrations were reduced in the leaves and roots of the plants under $\mathrm{NaCl}$ stress (Table 5). Application of Super-AB-A-200 polymer also reduced the concentration of salt in the soil water solution because of its salt-holding capability. Thus, minimal amounts of salts were taken up by the roots (Table 5). Furthermore, the concentrations of the $\mathrm{Cl}^{-}$and $\mathrm{Na}^{+}$in the Super-AB-A-200 polymer were diluted because of the water volume held in the polymer. The concentration of $\mathrm{Na}^{+}$ was $0.005 \mathrm{mM}$ and the concentration of $\mathrm{Cl}^{-}$was $0.004 \mathrm{mM}$ in Super-AB-A-200. Thus, root accumulation in or around the polymer resulted in less salt taken up by the plant roots, resulting in improved plant growth and gas-exchange under salinity stress (Tables 2-4). Moreover, the Super-AB-A-200 decreased the $\mathrm{Na}^{+}$concentration in the roots and leaves of the plants under $\mathrm{NaCl}$ stress (Table 5) due to the increased exchangeable $\mathrm{K}^{+}$ level in the Super-AB-A-200 polymer (Table 6), thereby improving salt exclusion capability of the plants. This result was in accordance with Shi et al. (2010) in which $\mathrm{K}^{+}$ levels in P. popularis roots and leaves were increased by amendment with SAPs of Stockosorb and Luquasorb on saline soil. Additionally, the Super-AB-A-200 polymer provided a $\mathrm{K}^{+}$source, consequently, uptake of $\mathrm{K}^{+}$increased in the plants treated with the polymer. $\mathrm{K}^{+}$enrichment led to a $\mathrm{K}^{+}$balance in the plants under salt stress, resulting in enhanced salt resistance, since the balance of $\mathrm{K}^{+} / \mathrm{Na}^{+}$is pivotal for tolerance to toxicity from ions (Munns and Tester, 2008; Sun et al., 2009a,b; Shabala and Cuin, 2008; Shi et al., 2010). Our results showed that the addition of Super-AB-A-200 polymer can improve access to quality water and a source of $\mathrm{K}^{+}$while decreasing contact with $\mathrm{Cl}^{-}$and $\mathrm{Na}^{+}$, thereby promoting resistance to salt stress.

\section{The effect of Super-AB-A-200 polymer on salt and drought tolerance}

The water consumption of $\mathrm{NaCl}+$ Drought-treated plants was reduced by $42 \%$, which was significantly greater than the plants under drought or salt stress alone, 2114\% (Table 3). Leaf gas-exchange showed a similar trend (Table 4). This was the consequence of an interaction of salinity and drought stresses. As the soil dried, the water availability decreased and the concentration of salt ions in the soil increased (Table 6). The roots could not absorb enough water to compensate for the water lost through the shoots, resulting in leaf damage. The impact of the co-existing drought and salinity stresses on dry weight was not as apparent as effect on short-term factors such as daily plant transpiration and leaf gas-exchange (Tables 2-4). There are three possible explanations as to why the Super-AB-A-200 polymer improved plant performance under drought and salinity stress in this study: (1) the water-filled Super-AB-A-200 polymer granules increased the access to water (Tables 4 and 3), (2) the exchangeable $\mathrm{K}^{+}$in this polymer promoted $\mathrm{K}^{+} / \mathrm{Na}^{+}$balance (Table 5), and (3) the polymer granules retained the salt ions, maintaining a lower concentration in the drying soil (Table 6). It is important to note that the effects of Super-AB-A-200 on plant dry weight and leaf gas-exchange were considerable (Tables 2-4). The addition of Super-AB-A-200 lengthened the duration of water supply to the plants and consequently decreased the damage caused by high soil $\mathrm{Cl}^{-}$and $\mathrm{Na}^{+}$in drought and salinity conditions (Table 6). As a result, the absorption of salts by roots and transportation of salt from the root to shoot were both effectively limited, resulting in improved plant growth and survival during an extended period of drought and salinity stress. 


\section{Conclusion}

According to the results, Super-AB-A-200 polymer could store water and nutrients in the sandy soil and release them under drought stress conditions. Besides, it could improve sandy soils and increase water-holding capacity. In addition, in saline conditions, Super-AB-A-200 retained $\mathrm{Cl}^{-}$and $\mathrm{Na}^{+}$in the soil solution because of their high water-holding capability and the exchangeable $\mathrm{K}^{+}$included in Super-AB-A-200 resulted in an amended $\mathrm{K}^{+} / \mathrm{Na}^{+}$balance in salinized plants. Furthermore, Super-AB-A200 helped E. globulus cuttings to resist interactive effects of salinity and drought stresses, which was essentially justified by their salt- and water-holding capabilities. Finally, it is recommended to use other types of hydrophilic polymers for the cultivation of other plants because of their effects on the other ions (heavy metals, calcium and etc). In addition, it is recommended to use Super-AB-A-200 polymer for the cultivation of other plants especially in arid and semi-arid regions with sandy soil. Because this polymer significantly improved the dry weights of the E. globulus stems, roots, leaves, and whole plants in the $\mathrm{NaCl}$, drought, and $\mathrm{NaCl}+$ Drought treatments, decreased the accumulation of $\mathrm{Cl}^{-}$and $\mathrm{Na}^{+}$in leaves and roots in the presence or absence of drought stress and could confine $\mathrm{Cl}^{-}$and $\mathrm{Na}^{+}$in $\mathrm{NaCl}+$ Drought-treated plant organs, reduced the $\mathrm{Cl}^{-}$and $\mathrm{Na}^{+}$levels in the saline soil in both the $\mathrm{NaCl}$ and the $\mathrm{NaCl}+$ Drought treatments and increased the $\mathrm{K}^{+}$concentration in the NaCl-treated soil. Therefore, by using this polymer, lower quality and amount of water could be used for cultivation and the cultivated lands could be extended by storing water in reservoirs.

\section{REFERENCES}

[1] Abedi Koupai, J., Mesforoush, M. (2009): Evaluation of Superabsorbent polymer application on yield, water and fertilizer use efficiency in cucumber (Cucumis sativus). J. Irrigation and Drainage 2: 100-111. (In Persian)

[2] Abedi-Koupai, J., Asad-Kazemi, J. (2006): Effects of a hydrophilic polymer on the field performance of an ornamental plant (Cupressus arizonica) under reduced irrigation regimes. - Iran. Polym. J 15: 715-725.

[3] Al-Omran, A.M., Al-Harbi, A.R. (1997): Improvement of sandy soils with soil conditioners. - In: Wallace, A., Terry, R.E. (Eds.) Handbook of Soil Conditioners: Substances that Enhance the Physical Properties of Soil. Marcel Dekker, Inc, New York, pages 363-384.

[4] Arbona, V., Iglesias, D.J., Jacas, J., Primo-Millo, E., Talon, M., Go' mez-Cadenas, A. (2005): Hydrogel substrate amendment alleviates drought effects on young citrus plants. Plant Soil 270: 73-82.

[5] Bouranis, D.L., Theodoropoulus, A.G., Drossopoulus, J.B. (1995): Designing synthetic polymers as soil conditioners. Commun. - Soil Sci. Plant Anal 26: 1455-1480.

[6] Bouwer, H. (2002): Integrated water management for the 21st century: Problems and solutions. - J Irrig Drain Eng 128: 193-202.

[7] Fazeli-Rostampoor, M., Theghatol Islami, M.J., Mousavi, S.G. (2011): The effect of drought stress and polymer (Superabsorbent A 200) on yield and water use efficiency of corn (Zea mays L.) in Birjand region. - Journal of Environmental Stress in Crop Sciences 4: 11-19. (In Persian)

[8] Gornall, J., Betts, R., Burke, E., Clark, R., Camp, J., Willett, K., Wiltshire, A. (2010): Implications of climate change for agricultural productivity in the early twenty-first century. - Philos. Trans. R. Soc. B: Biol. Sci 365: 2973-2989. 
[9] Han, Y.G., Yang, P.L., Luo, Y.P., Ren, S.M., Zhang, L.X., Xu, L. (2010): Porosity change model for watered super absorbent polymer-treated soil. - Environ. Earth Sci 61: 1197-1205.

[10] Kasgoz, H., Durmus, A., 2008. Dye removal by a novel hydrogel-clay nanocomposite with enhanced swelling properties. - Polymers for Advanced Technologies 19: 838-845.

[11] Kasgoz, H., Durmus, A., Kasgoz, A. (2008). Enhanced swelling and adsorption properties of AAm-AMPSNa/clay hydrogel nanocomposites for heavy metal ion removal. Polymers for Advanced Technologies 19: 213-220.

[12] Kosemund, K., Schlatter, H., Ochsenhirt, J.L., Krause, E.L., Marsman, D.S., Erasala, G.N. (2009): Safety evaluation of Superabsorbent baby diapers. - Regulatory Toxicology and Pharmacology 53: 81-89.

[13] Lentz, R.D., Sojka, R.E., Robbins, C.W. (1998): Reducing phosphorus losses from surface irrigated fields: emerging polyacrylamide technology. - J. Environ. Qual 27: 305312.

[14] Li, X., He, J., Hughes, J., Liu, Y., Zheng, Y. (2014): Effects of super-absorbent polymers on a soil-wheat (Triticum aestivum L.) system in the field. - Applied Soil Ecology 73: 5863.

[15] Marandi, G.B., Hariri, S., Mahdavinia, G.R. (2009): Effect of hydrophobic monomer on the synthesis and swelling behaviour of a collagen-graft-poly[(acrylic acid)-co-(sodium acrylate)] hydrogel. - Polym. Int 58: 227-335.

[16] Mikkelsen, R.L. (1999): Using hydrophilic polymers to control nutrient release. Nutr. Cycl. - Agroechosys 38: 53-59.

[17] Munns, R., Tester, M. (2008): Mechanisms of salinity tolerance. - Ann. Rev. Plant Biol 59: 651-681.

[18] Osareh, M.H., Shariat, A. (2009): Salinity resistance in germination stage and growth stage in some Eucalyptus species. - J. Agric. Sci. Natur. Resour 15: 145-157.

[19] Peterson, D. (2002): Hydrophilic polymers and uses in landscape. - Horticul. Sci 75: 1016.

[20] Puoci, F., Iemma, F., Spizzirri, U.G., Cirillo, G., Curcio, M., Picci, N. (2008): Polymer in agriculture: A review. - American Journal of Agricultural and Biological Sciences 3: 299-314.

[21] Rahab Resin Co. (2016): Rahab Resin Company. Access date: 9 October 2016. http://www.bizearch.com/company/Rahab_Resin_Co_280864.htm.

[22] Shabala, S., Cuin, T.A. (2008): Potassium transport and plant salt tolerance. - Physiol. Plant 133: 651-669.

[23] Shi, Y., Li, J., Shao, J., Deng, Sh., Wang, R., Li, N., Sun, J., Zhang, H., Zhu, H., Zhang, Y., Zheng, X., Zhou, D., Huttermann, A., Chen, Sh. (2010): Effects of Stockosorb and Luquasorb polymers on salt and drought tolerance of Populus popularis. - Scientia Horticulturae 124: 268-273.

[24] Sojka, R.E., Entry, J.A. (2000): Influence of polyacrylamide application to soil on movement of microorganisms in runoff water. - Environ. Pollut 108: 405-412.

[25] Storey, R. (1995): Salt tolerance, ion relations and the effects of root medium on the response of citrus to salinity. - Plant Physiol 22: 101-114.

[26] Sun, J., Chen, S., Dai, S., Wang, R., Li, N., Shen, X., Zhou, X., Lu, C., Zheng, X., Hu, Z., Zhang, Z., Song, J., Xu, Y. (2009a): NaCl-induced alternations of cellular and tissue ion fluxes in roots of salt-resistant and salt-sensitive poplar species. - Plant Physiol 149: $1141-1153$.

[27] Sun, J., Dai, S., Wang, R., Chen, S., Li, N., Zhou, X., Lu, C., Shen, X., Zheng, X., Hu, Z., Zhang, Z., Song, J., Xu, Y. (2009b): Calcium mediates root $\mathrm{K}+/ \mathrm{Na}+$ homeostasis in poplar species differing in salt tolerance. - Tree Physiol 29: 1175-1186.

[28] Teimouri, F., Sharifan, H. (2013): The evaluation of monovalent salts effect on Superabsorbent hydrogels hydrate. - The First National Conference in Drainage and Sustainable Agriculture, pages 7. (In Persian) 
[29] Viero, P.W.M., Little, K.M. (2006): A comparison of different planting methods, including hydrogels, and their effect on eucalypt survival and initial growth in South Africa. - South Afr. For. J 208: 1-9.

[30] Wang, L., Zhang, J.P., Wang, A.Q. (2008a): Removal of methylene blue from aqueous solution using chitosan-g-poly (acrylic acid)/montmorillonite superadsorbent nanocomposite. - Colloid Surface A 322: 47-53.

[31] Wang, R., Chen, S., Deng, L., Fritz, E., Huttermann, A., Polle, A. (2007): Leaf photosynthesis, fluorescence response to salinity and the relevance to chloroplast salt compartmentation and anti-oxidative stress in two poplars. - Trees 21: 581-591.

[32] Wang, R., Chen, S., Zhou, X., Shen, X., Deng, L., Zhu, H., Shao, J., Shi, Y., Dai, S., Fritz, E., Huttermann, A., Polle, A. (2008b): Ionic homeostasis and reactive oxygen species control in leaves and xylem sap of two poplars subjected to $\mathrm{NaCl}$ stress. - Tree Physiol 28: 947-957.

[33] Yadollahi, A., Teimoori, N., Abdoosi, V., Sarikhani-Khorami, S. (2012): Impact evaluation of Superabsorbent and organic matters in retention of water and establishment of Almond gardens in rainfed conditions. - Journal of Water Research in Agriculture 26: 95-106. (In Persian) 